Free Radic Biol Med. 2012 August 15; 53(4): 721-729. doi:10.1016/j.freeradbiomed.2012.05.037.

\title{
Role of GSTM1 in Resistance to Lung Inflammation
}

\author{
Weidong $\mathbf{W u}^{1,2,{ }^{*}, \text { David Peden }}{ }^{1,2}$, and David Diaz-Sanchez ${ }^{3}$ \\ ${ }^{1}$ Department of Pediatrics, University of North Carolina, Chapel Hill, NC 27599, USA \\ ${ }^{2}$ Center for Environmental Medicine, Asthma, and Lung Biology, University of North Carolina, \\ Chapel Hill, NC 27599, USA \\ ${ }^{3}$ Environmental Public Health Division, National Health and Environmental Effects Research \\ Laboratory, US Environmental Protection Agency, Chapel Hill, NC 27599, USA
}

\begin{abstract}
Lung inflammation resulting from oxidant/antioxidant imbalance is a common feature of many lung diseases. In particular, the role of enzymes regulated by the NF-E2-related factor 2 (Nrf2) transcription factor has recently received increased attention. Among these antioxidant genes, the glutathione S-transferase mu 1 (GSTMI) has been most extensively characterized since it has a null polymorphism which is highly prevalent in the population and associated with increased risk of inflammatory lung diseases. Present evidence suggests that GSTM1 acts through interactions with other genes and environmental factors, especially air pollutants. Here, we review GSTM1 gene expression and regulation and summarize the findings from epidemiological, clinical, animal and in vitro studies on the role played by GSTM1 in lung inflammation. We discuss limitations in the existing knowledge base and future perspectives and evaluate the potential of pharmacologic and genetic manipulation of the GSTM1 gene to modulate pulmonary inflammatory responses.
\end{abstract}

\section{Keywords}

GSTM1 polymorphism; air pollution; lung inflammation; $\mathrm{NrF} 2$

\section{Introduction}

Chronic inflammation is a feature of many common lung diseases, such as asthma and chronic obstructive pulmonary disease (COPD) $[1,2]$. There is now substantial evidence that oxidative stress plays an important role in the injurious and inflammatory responses central to many lung diseases. As a part of endogenous metabolism, as well as in response to challenge by inhaled environmental agents, the lung continuously generates reactive forms of oxygen, as well as free radical species [3]. Normally, moderate levels of oxidant species are thought to function as localized, transient and reversible signals to promote cell proliferation and survival. However, when the balance between oxidants and antioxidants shifts in favor of the former, from either an excess of oxidants, depletion of antioxidants, or decreased expression of antioxidant enzymes, oxidative stress occurs. Oxidative stress

\footnotetext{
(C) 2012 Elsevier Inc. All rights reserved.

"Corresponding author: Weidong Wu, Ph.D., Center for Environmental Medicine, Asthma, and Lung Biology, University of North Carolina,, 104 Mason Farm Road, Chapel Hill, NC 27599, Tel. (919)8432714, Fax. (919)9669863 Weidong_Wu@med.unc.edu.

Publisher's Disclaimer: This is a PDF file of an unedited manuscript that has been accepted for publication. As a service to our customers we are providing this early version of the manuscript. The manuscript will undergo copyediting, typesetting, and review of the resulting proof before it is published in its final citable form. Please note that during the production process errors may be discovered which could affect the content, and all legal disclaimers that apply to the journal pertain.
} 
produces not only direct injurious effects in the lung through oxidation of proteins, DNA, and lipids, but some of these oxidized molecules (electrophils) also activate proinflammatory molecular mechanisms [4-6]. In addition, inflammation itself is an oxidative process that causes generation of reactive oxygen species (ROS) by activated cells. Inflammation and oxidative stress are thus intricately linked and a self-perpetuating cycle can occur when compensatory antioxidant processes are deficient.

The oxidant sources in the lungs include cell-derived endogenous and inhaled oxidants [79]. Lung cells are protected against oxidant challenge by well developed nonenzymatic and enzymatic antioxidant systems. The nonenzymatic antioxidants are low molecular weight compounds such as vitamins (vitamins $\mathrm{C}$ and $\mathrm{E}$ ), beta carotene, uric acid, and glutathione (GSH). The enzymatic antioxidants include superoxide dismutases, catalase, glutathione peroxidase, heme oxygenase-1, small molecular weight redox proteins, and glutathione Stransferases (GSTs) [6].

The mammalian GST gene family consists of at least 16 genes assigned to eight protein enzyme classes based on their substrate specificity, structure, and kinetic behavior: alpha (GSTA), kappa (GSTK), mu (GSTM), omega (GSTO), pi (GSTP), sigma (GSTS), theta (GSTT), and zeta (GSTZ) [10-12]. The human GST genes are located on at least seven chromosomes [11]. They encode three major families of GST enzymes: cytosolic, mitochondrial, and microsomal proteins, of which the cytosolic GSTs constitute the largest family [13]. Most $G S T$ classes show a high degree of polymorphism and include several subtypes. Variant $G S T$ alleles have been identified within the general population and correlated with interindividual variations in protein level and enzymatic activity. The most extensively studied variant $G S T$ s include the GSTM1 and GSTT1 deletion (null) alleles and the $G S T P 1$ valine allele (Val/Val) [14]. The significance of $G S T M 1$ polymorphism in human was first recognized in cancer studies demonstrating that individuals carrying the GSTM1 deletion allele were at increased risk for colon and lung cancers $[15,16]$. Other consequences of the genetic polymorphisms include potential differences in tolerance of toxic agents. To date, the GSTM1 is the most comprehensively studied among all GSTs, and is suggested to play an important role in the response to oxidative stress [17], particularly in the lung $[18,19]$.

\section{Genetic polymorphisms and function of GSTM1}

The GSTM gene class is one of the most highly evolved mammalian $G S T$ classes. In mice there are 7 GSTM genes [13,20]. GSTM1 is the most abundantly expressed among all of the GST genes in mouse kidney [21]. In humans, five GSTM genes are encoded by a 100-kb gene cluster on chromosome 1p13.3 arranged as 5' - GSTM4-GSTM2-GSTM1-GSTM5GSTM3-3' and are known to be highly polymorphic [22-24]. The GSTM1 gene contains four different alleles allowing for several M1 class polymorphisms, designated as GSTM1*0, GSTM1*A, GSTM1*B and GSTM1*1 $1 \times 2$ alleles [25-27]. GSTM1*0 (GSTM1 null allele) is deleted, and homozygotes express no protein [28], while $G S T M 1^{*} A$ and $G S T M 1{ }^{*} B$ differ by a single base in exon 7 . The products of these latter two genes combine to form active, homo- and hetero-dimeric, enzymes [11,29-31]. A unique GSTM1 variant $d G S T M 1 * 1 \times 2$, containing a duplicated GSTM1 gene was identified among a Saudi Arabian population [32]. The GSTM1 null allele arose from a recombination event during evolution between 2 highly homologous regions flanking this locus, resulting in deletion of a 20-kb segment $[23,33]$. The prevalence of GSTM1 deletion polymorphisms varies across ethnic groups, from $18 \%$ to $66 \%$ (median, 50\%), with the exception of Asians, for whom it is $38 \%-58 \%[34,35]$. The cDNAs encoded by GSTM1 and GSTM2 share a remarkable 99\% sequence identity [36]. The fact that GSTM1 and GSTM2 are physically linked suggests that the frequent deletion of the GSTM1 locus is caused by unequal crossing-over [22,23]. 
Moreover, $G S T M 1{ }^{*} A$ and $G S T M 3^{*} B$ are in linkage disequilibrium suggesting that in some cases, links between clinical phenotype and GSTM1 genotypes may reflect polymorphism in GSTM3 or, indeed other mu class $G S T$ genes [11,37]. In addition to genetic polymorphisms, the tissue distribution of GSTs is subject to great individual variation. Quantitative analysis of GSTM1 protein in various human tissues revealed that the liver is the richest source of cytosolic GSTM1. The other sources include testis, lungs, stomach, brain, kidneys, heart, breast, colon, pituitary, and the lymphocytes [25,38].

The major function of all GSTs has been considered to be the catalysis of the conjugation of endogenous and xenobiotic electrophiles (e.g. products of oxidative stress, environmental pollutants, and carcinogens) with GSH, thereby neutralizing their electrophilic sites, and rendering the products more water-soluble and excretable [39]. GSTs function as homo- and hetero-dimeric combinations of subunits within a class, but not between classes [38]. Each subunit with an estimated molecular mass of $\sim 25 \mathrm{kDa}$ contains a catalytically independent GSH-binding site in the amino-terminal domain and a hydrophobic substrate binding site in the carboxy-terminal domain [40].

In recent years a great deal of evidence has shown that GSTs, and in particular GSTM1 and GSTP1, also have several nonenzymatic functions, in which they regulate a number of cellular processes that contribute to the intrinsic ability of cells to survive genotoxic, metabolic and oxidative stress [40-42]. The best-characterized of these properties is the interaction with other functional cellular proteins, such as c-Jun N-terminal kinase (JNK), tumor necrosis factor receptor associated factor, apoptosis-signal regulating kinase (ASK) [43,44], protein kinase C (PKC), and tissue transglutaminase, resulting in significant functional alteration of the binding partners or post-translational modification and functional alteration of the GST protein itself [45].

\section{GSTM1 expression and regulation}

The expression level of GSTs has been shown to be a factor that determines the cellular sensitivity to a broad spectrum of toxic chemicals. However, the regulation of the expression of the GST gene families is complex, as they exhibit sex-, age-, tissue-, and species-specific patterns of expression $[38,40]$. For example, GSTP1, originally isolated from placenta, is found mainly in brain, lung, and heart; its expression in liver decreases during embryonic development, becoming very low in adult tissue [46-48]. GSTM1 and GSTT1 are found in relatively low concentrations in many organs including the lungs [49]. The expression of GSTM genes in human lung tissue is most intense in the bronchial epithelium, decreasing in the distal airways [50-52].

GST expression can be induced by a structurally diverse range of xenobiotics and, to date, at least 100 chemicals have been identified that induce GSTs [53,54]. Many of the GST inducers are themselves substrates for these enzymes, or are metabolized to compounds that can serve as GST substrates [38]. These inducers effect transcriptional activation of GST genes through either the antioxidant-responsive element (ARE) [55], a Barbie box element, the xenobiotic-responsive element, the GST P enhancer 1, or the glucocorticoid-responsive element, which may involve interactions with many transcription factors including aryl hydrocarbon receptor, CCAAT-enhancer binding protein- $\beta$, Maf, Nrl, Jun, Fos, hepatic nuclear factor-1, peroxisome proliferator-activated receptors, and nuclear factor $\mathrm{kB}(\mathrm{NFkB})$ $[38,54]$. The most significant development in this field has been the recent identification of a transcriptional factor, NF-E2-related factor 2 (Nrf2) that appears to bind to the ARE sequences and enhance transcription of GSTs [56-60]. Nrf2 is ubiquitously expressed in a wide range of tissues and cell types. Under normal conditions, Keap1 anchors the Nrf2 transcription factor within the cytoplasm targeting it for ubiquitination and proteasomal 
degradation. When cells are exposed to chemopreventive agents and oxidative stress, a signal involving phosphorylation and/or redox modification of critical cysteine residues in Keap1 inhibits the enzymatic activity of the E3 ubiquitin ligase complex, resulting in decreased Nrf2 ubiquitination and degradation. As a consequence, free Nrf2 translocates into the nucleus and in combination with other transcription factors transactivates the AREs/ electrophile response elements of many cytoprotective genes including GSTMlas well as Nrf2 itself [61]. In addition to transcriptional regulation, GST expression can also be controlled by posttranscriptional modulation of mRNA stability and protein modification [38,54]. Posttranslational modification of protein can also affect the GST activity and may, therefore, represent another mechanism of control. The activity of GSTM enzymes can be increased by treatment with ROS [38].

\section{Association of GSTM1 with lung inflammation}

Oxidant/antioxidant imbalance is a hallmark of lung inflammation [62]. Genetic polymorphisms associated with reduced activity of antioxidant enzymes including GSTs are therefore relevant to studies of lung inflammatory disease susceptibility. Moreover, the etiology of inflammatory lung diseases involves a complex interplay between genetic background and exposure to multiple environmental stimuli [63]. GSTM1 gene has been a natural candidate in studies of susceptibility to inflammatory airway diseases with environmental components because of the high prevalence of the null polymorphism and its role in detoxification [64-68].

\subsection{Epidemiological studies}

Asthma and chronic obstructive pulmonary disease (COPD) are two common inflammatory lung diseases the incidence of which is increasing globally $[9,69]$. The association of GSTM1 polymorphism with the risk of these two diseases has been widely investigated [67]. Asthma is a polygenetic or multifactorial illness characterized by chronic airway inflammation leading to reversible airflow obstruction [70,71]. GSTM1 has been listed as one of at least 118 genes to date associated with an asthma-related phenotype [72]. Two common deletion polymorphisms of GSTM1 and GSTT1 genes have been associated with asthma in children and adults [73-76]. In addition, a single nucleotide polymorphism in GSTM1 was also associated significantly with asthma in an African American urban population [77]. In this study, GSTM1 rs412543 C carriers were almost 3 times as likely to have asthma compared to individuals without the C allele. GSTM1 CCG haplotype was associated with a 3 fold increase in the odds of asthma. However, a negative association between the GTSM1 null genotype and asthma phenotypes was also reported [75,78-82]. To resolve these conflicting results, a meta-analysis of GSTM1 effects has been conducted but the conclusion did not favor a substantial role of GSTM1 gene by itself in the development of asthma, likely due to extreme between-study heterogeneity and publication bias [83]. In a subsequent meta-analysis of antioxidant genes, the same authors concluded that the GSTM1 association with asthma risk needs to consider gene-gene and gene-environment interactions [66]. The GSTM1 enzyme has overlapping substrate specificities with other GST enzymes, a deficiency in one isoform may be compensated by another. Thus, it is perhaps not surprising that children and adults with combined deletion polymorphisms of the GSTM1 and GSTT1 genes were found to be at a higher risk of developing asthma [73-76,84-86]. In addition, $G S T M 1$ can act as a modifier gene of GSTPINAD(P)H:quinine oxidoreductase 1 (NQO1), or nitric oxide synthase genes for the risk of childhood asthma [87-92]. Besides gene-gene interaction, failure to account for environmental exposures might partly explain not only the heterogeneity of results across studies, but also the overall negative findings. Strong environmental effects on asthma phenotypes could mask modest genetic effects and, more importantly, gene-environment interactions could make the effects of GSTM1 gene 
become substantial only in the presence of oxidant exposures and not detectable at a population level [83].

Diisocyanate-induced occupational asthma is a dramatic example of gene-environment interactions causing lung inflammation [67]. The asthma risk related to diisocyanate exposure was associated with the GSTM1 null genotype [93], which also involved the interaction between $G S T M 1$ null genotype and $N$-acetyltransferases [94]. The underlying mechanism might be due to the deficiency of biotransformation of isocyanates and excretion of metabolic products in the GSTM1 null workers [95]. Aside from occupational exposure, air pollution has attracted much attention in its contribution to the development of asthma and asthma exacerbations [96,97]. Environmental tobacco smoke (ETS) or secondhand smoke, ambient air pollutants, such as ozone and diesel exhaust particles (DEPs), and endotoxin and/or other pathogen-associated molecular patterns are the ambient exposures studied most frequently for interactions with GSTM1 polymorphisms in asthma [98-100]. Ozone is a gaseous air pollutant associated with an increased risk of asthma [97,101,102]. Asthmatic children with GSTM1 null and GSTP1 (Val/Val) genotypes appear more susceptible to developing respiratory symptoms related to ozone exposure [103]. ETS is an extremely potent oxidant mixture and important in the etiology of childhood asthma [8,98]. In the Children's Health Study cohort [104], the effects of in utero exposure to maternal smoking on asthma and wheezing occurrence were largely restricted to children with GSTM1 null genotype. Among GSTM1 null children, in utero exposure was associated with increased prevalence of early onset asthma, asthma with current symptoms, persistent asthma, lifetime history of wheezing, wheezing with exercise, wheezing requiring medication, and emergency room visits in the past year. Among children with GSTM1 sufficient genotype, in utero exposure was not associated with asthma or wheezing. Others have shown that children who either had the GSTM1 null genotype or were homozygous for the GSTP1 (Val/Val) allele had increased risk of asthma at younger ages related to ETS, with an increased risk for decreased lung function in adolescence [105]. In addition, GSTM1 deficiency was also shown to increase the adverse health effects including asthma and atopy of in utero and current ETS exposure [106]. In a recent study GSTM1 null genotype itself was not significantly associated with asthma. However, the GSTM1 null genotype could modify the association of the NQO1 polymorphism with asthma in children exposed to ETS [91]. It should be noted that, to date, evidence for gene-air pollution interactions on asthma have been reported only in children $[107,108]$. Susceptibility to air pollution in early life may differ from that in adulthood [109]. For example, a recent study in adults showed no significant associations of GSTM1 polymorphism with asthma either alone or in combination with NQO1 SNPs. The lack of consistence with previous analyses could be related to the heterogeneity of effects in adults compared with children [109]. Intriguingly, there is emerging evidence that the risk conferred by GSTM1 may be hereditable. The Children's Health Study cohort found that children of non-smoking mothers but with maternal grand-mother who smoked had a two-fold risk of asthma. A further study by the same group demonstrated that smoking-related effects on LINE1 methylation could be seen in GSTM1 null children exposed to cigarette smoke [110].

COPD is another major inflammatory lung disease attributable to environmental exposures, especially cigarette smoking, and genetic susceptibility [69,111-113]. Candidate susceptibility genes have been selected in terms of putative pathogenesis of COPD such as the protease-antiprotease imbalance, oxidative stress and antioxidants, and cytokines and chemokines related to airway inflammation [114]. Most studies on these candidate genes have not been consistently replicated possibly due to genetic heterogeneity between different study populations, phenotypic differences, population stratification, multiple statistical testing, small sample sizes, and random error $[111,115,116]$. However, longitudinal studies of decline in lung function, meta-analyses of candidate gene studies, and family-based 
linkage analyses suggest that variants in GSTM1 and other candidate genes are associated with susceptibility to COPD [114,117-120]. Again, it is likely that GSTM1 acts in an epistatic fashion. For example, although the polymorphism of GSTM1, GSTT1 or GSTP1 genes was found unlikely to be individually involved in the pathogenesis of COPD in a Chinese population [121], the combined GSTM1 and GSTT1 null genotype was a significant risk factor for developing COPD in Chinese smokers [122]. The co-existence of the GSTM1 null allele with other genetic polymorphisms, such as the microsomal epoxide hydrolase exon-3 and homozygous GSTP1 (Val/Val) alleles, also plays a significant role in the development of COPD [118,119,123-125]. In addition, the expression levels of GSTM1 mRNA was significantly decreased in the COPD lung tissues compared with those in nonCOPD tissues, and most of these decreases were significantly correlated with the degree of airflow limitation and cigarette smoking [126]. In a study on patients with non-small-cell lung cancer the presence of at least one active allele in GSTM1 gene had a protective effect against the development of COPD [127].

\subsection{Controlled human studies}

An earlier study examining the effects of GSTM1 on ozone-induced serum clara cell protein CC16 (a biomarker of lung injury) release showed that increases in levels of CC16 and decreases in lung function were more pronounced in subjects with the combined GSTM1 null and NQO1 CC (wild-type) genotype in healthy volunteers [128]. In a controlled ozone exposure study ( $0.1 \mathrm{ppm}$ for $2 \mathrm{~h}$ ), the same group observed that subjects with the combined GSTM1 null plus NQO1 CC genotype had greater increases in biomarkers of inflammation and oxidative stress relative to subjects with other genotypes [129]. Our studies with healthy young adult volunteers also demonstrated that the GSTM1 null genotype is associated with increased airways neutrophilic inflammation 24 hours after ozone exposure ( $0.4 \mathrm{ppm}$ for 2 h) [130]. Interestingly, this association between the GSTM1 null genotype and neutrophilic lung inflammation was not observed in healthy volunteers exposed to $0.06 \mathrm{ppm}$ ozone [131]. In addition, no difference in inflammatory response (sputum neutrophil count) to ozone was observed between asthmatic patients with or without the combined GSTM1 null and NQO1 wild-type genotypes [132]. These results suggest that exposure conditions and subject health status can influence the evaluation on the role of GSTM1 in lung inflammation.

In a separate study, we investigated whether the GSTM1 null genotype is a risk factor for the development of exacerbated inflammatory responses to inhaled endotoxin [133]. It was shown that GSTM1-null healthy volunteers had significantly elevated neutrophil counts in their sputum after endotoxin challenge (20,000 endotoxin units). In contrast, GSTM1 sufficient volunteers showed statistically significant, but blunted increases in neutrophils/mg sputum, suggesting that the GSTM1 null genotype is a risk factor for the increased acute respiratory inflammatory response to inhaled endotoxin.

Particulate pollution, such as DEPs, is associated with the occurrence of asthma and allergy [134]. Individuals with the GSTM1 null genotype showed enhanced nasal allergic responses in the presence of DEPs [100], indicating that GSTM1 could modify the adjuvant effect of DEPs on allergic inflammation. In addition, GSTM1 has been shown to be an important cytoprotective factor that reduces allergen-induced airway responses upon exposure to second hand smoke [135]. It should be noted however, that these studies on DEP and secondhand smoke only examined nasal responses and the upper airways and further verification of the results in the lung or lower airways is expected.

\subsection{Animal studies}

The use of knockout mice with a single disrupted gene, such as GSTM1, is expected to pinpoint the role of GSTM1 in the pathogenesis of lung inflammation. To date, no studies 
using GSTM1 knockout mice have been reported in this field although GSTM1 knockout mice have been used for other studies [136,137]. However, in a mouse model of acute lung injury, the transcription factor $N r f 2$ was identified as a candidate gene that protected against oxidant injury via upregulation of antioxidant and phase II enzyme genes including GSTM1 [138]. In another study the DEP-induced DNA adduct formation was enhanced in the lung of Nrf2 knockout mice [139].

\subsection{In vitro studies}

The association of GSTM1 with inflammatory responses has not been extensively investigated in vitro. In a recent study, we showed that knockdown of GSTM1 expression in a human bronchial epithelial cell line (BEAS-2B) enhances ozone-induced NFKB activation and interleukin 8 (IL-8) production [140]. This finding was confirmed in primary human bronchial epithelial cells from healthy subjects with GSTM1-sufficient or -null genotypes. Another study with human nasal epithelial cells showed that Nrf2 knockdown correlated with a significant increase in influenza virus entry and replication [141].

\section{Possible mechanisms of GSTM1-modulated lung inflammation}

The possible mechanisms underlying GSTM1-modulated lung inflammation are largely unknown. It has been well recognized that oxidants initiate lung inflammation through their direct and/or indirect activation of stress kinases and redox-sensitive transcription factors, such as NFkB, leading to increased expression of a battery of distinct pro-inflammatory mediators [142].

As described previously, GSTM1 detoxifies electrophilic compounds by catalyzing their conjugation with reduced GSH. It is presumed that intermediate electrophilic metabolites, arising in the first phase of detoxification, are not metabolized in GSTM1-null asthmatic patients and are not excreted. These intermediate metabolites may damage cells and generate oxidative stress, and thereby contribute to the pathogenesis of asthma [85]. In addition to this well-characterized catalytic activity, recent evidence has suggested that GSTM1 may control oxidative stress and inflammation through the regulation of intracellular signaling pathways by its effects on certain small molecules or by protein-protein interactions with critical kinases [143]. The ligand-binding capacity of GSTM1 results in the negative regulation of signaling pathways through sequestration of signaling kinases [144]. For example, GSTM1 can interact with the N-terminal portion of ASK1, inhibiting oxidative stress-induced ASK1-dependent apoptosis [43]. ASK1 is a mitogen-activated protein kinase (MAPK) kinase kinase that activates the JNK and p38 pathways leading to cytokine- and stress-induced apoptosis $[42,145]$. Under normal conditions, ASK1 exhibits low activity because of its sequestration by GSTM1. This protein/protein interaction forms a GSTM1/ ASK1 complex, which is dissociated under oxidative stress, leading to the release and activation of ASK1 [146,147]. Overexpression of GSTM1 has been shown to repress ASK1 activity and ASK1-induced apoptosis [44]. Mitogen-activated protein kinase/extracellular signal-regulated kinase kinase kinase 1 (MEKK1) is an important component in the stressactivated protein kinase pathway. GSTM1 has been shown to inhibit MEKK1 activity induced by cellular stresses through direct binding of MEKK1 [148], leading to suppression of MEKK1-mediated apoptosis. Recent evidence also showed GSTM1 could facilitate the addition of glutathione to cysteine residues in target proteins ( $S$-glutathionylation) [149], regulating lung inflammation [150].

Knockdown of GSTM1 could increase the production of ROS [151], and enhance the activity of inflammation-related transcription factor NFkB in ozone-exposed human bronchial epithelial cells, leading to IL-8 upregulation [140]. Interestingly, the interaction between broccoli consumption and GSTM1 genotype resulted in complex changes to 
transforming growth factor beta 1 and epidermal growth factor signaling pathways associated with inflammation [152].

\section{Clinical implications of GSTM1 manipulation and antioxidant supplementation}

Given the critical role that oxidative stress plays in lung inflammation, induction of antioxidant enzymes could constitute a powerful potential chemopreventive approach against initiation and progression of lung inflammation. Sulforaphane is an isothiocyanate that activates the transcription factor Nrf2. The richest source of sulforaphane is from cruciferous vegetables and it is the most potent known naturally occurring inducer of the phase II enzyme genes [153]. It has been shown that sulforaphane significantly augmented expression of GSTM1 and its enzymatic activity, and sulforaphane pretreatment inhibited DEP-induced production of pro-inflammatory cytokines by human bronchial epithelial cells [154]. In animal models, it can reduce inflammation induced by agents such as cigarette smoke [155]. The induction of GSTM1 by sulforaphane could also block DEP-induced enhancement of immunoglobulin (Ig) E production in B cells [156]. Promisingly, in a human study, we showed that dietary sulforaphane safely and effectively induced expression of Phase II enzymes including GSTM1 in the upper airway of human subjects, suggesting the potential of enhancement of Phase II enzyme expression as a novel therapeutic strategy for oxidant induced lung diseases [157].

In either the presence or absence of GSTM1 enzyme, supplementation of antioxidants remains a therapeutic option to lung inflammation treatment. As the specific substrate of GSTM1, GSH is the predominant non-protein thiol in the cells and is a key player in the maintenance of the cellular redox status [158]. However, GSH is not well absorbed across the gastrointestinal tract [159]. Thus, oral supplementation does not improve glutathione status, nor reduce markers of oxidative stress in healthy adults, and thus routine supplementation may not offer health benefits in the absence of disease or oxidative challenge [160]. In contrast, supplementation of other antioxidants including vitamins $\mathrm{C}$ and E has been shown to have protective effects in asthmatic children with the GSTM1 null genotype in Mexico City [18].

\section{Conclusion and perspectives}

In summary, from the overview of epidemiological studies, controlled inhalation studies, and the limited animal and in vitro studies currently available, GSTM1 appears to play an important role in the pathogenesis of lung inflammation. The inconsistent epidemiological results may be, on the one hand, due to limited sample size, ambiguous definition of clinical and pathological phenotypes, ethnic population grouping, population admixture (diversity), publication bias and other factors contributing to the large heterogeneity of studies $[66,161,162]$. On the other hand, intragenic, gene-environment, and gene-diet interactions also significantly confounds the evaluation of the association of GSTM1 with lung inflammation [65]. Thus, the approaches that consider potential interaction between and among genes, smoke exposure and antioxidant intake are needed to fully characterize the role of oxidant/antioxidant balance in pathogenesis [163]. In reorganization of the overlapping substrate specificities, simultaneous determination of all GST genotypes appears to be a prerequisite for reliable interpretation of the role of the GSTM1 in lung inflammation [29]. In addition, the role of epigenetic mechanisms needs to be considered along with gene-environment interactions, since epigenetic changes may have profound effects on disease susceptibility [1]. The completion of the Human Genome Project, the HapMap project, technological advances in genotyping and the potential of genome-wide association analysis has led to a rapid increase in the number of susceptibility candidate 
genes for asthma and other environmentally induced inflammatory pulmonary diseases.

Most of the studies, however, lack information on the mechanisms by which the polymorphisms could affect individual's susceptibility to these lung diseases. Confirmation of the functional consequences of specific genetic polymorphisms ultimately depends on performing functional studies [1,67]. In this case, GSTM1 knockout mice and lung cells will provide unique tools for characterization of the role of GSTM1 in lung inflammation.

\section{Acknowledgments}

The authors specifically thank Drs. James Samet and Philip Bromberg for their invaluable review of this manuscript. The work described in this review has been supported by the National Institute of Health U19AI077437 and R01ES016535. Although the research described in this article has been funded in part by the United States Environmental Protection Agency through cooperative agreement CR83346301 with the Center for Environmental Medicine, Asthma and Lung Biology at the University of North Carolina at Chapel Hill, it has not been subjected to the Agency's required peer and policy review, and therefore does not necessarily reflect the views of the Agency and no official endorsement should be inferred. Mention of trade names or commercial products does not constitute endorsement or recommendation for use.

\section{List of Abbreviations}

GSTM1 glutathione S-transferase mu 1

IL-8 interleukin 8

ROS reactive oxygen species

$\mathbf{I} \mathbf{x} \mathbf{B a} \quad$ inhibitory protein

NF $\times B \quad$ nuclear factor $\kappa B$

COPD chronic obstructive pulmonary disease

GSH glutathione

JNK c-Jun N-terminal kinase

Ask apoptosis-signal regulating kinase

PKC protein kinase $\mathrm{C}$

ARE antioxidant-responsive element

NFkB nuclear factor kB

NrF2 NF-E2-related factor 2

NQO1 NAD(P)H:quinine oxidoreductase 1

DEPs diesel exhaust particles

ETS environmental tobacco smoke

MAPK mitogen-activated protein kinase

MEKK1 mitogen-activated protein kinase/extracellular signal-regulated kinase kinase kinase 1

\section{References}

1. Adcock IM, Ford P, Ito K, Barnes PJ. Epigenetics and airways disease. Respir Res. 2006; 7:21. [PubMed: 16460559]

2. Adcock IM, Ito K, Barnes PJ. Histone deacetylation: an important mechanism in inflammatory lung diseases. Copd. 2005; 2:445-455. [PubMed: 17147010] 
3. Biswas SK, Rahman I. Environmental toxicity, redox signaling and lung inflammation: the role of glutathione. Mol Aspects Med. 2009; 30:60-76. [PubMed: 18760298]

4. Rahman I, MacNee W. Role of transcription factors in inflammatory lung diseases. Thorax. 1998; 53:601-612. [PubMed: 9797762]

5. Lang JD, McArdle PJ, O'Reilly PJ, Matalon S. Oxidant-antioxidant balance in acute lung injury. Chest. 2002; 122:314S-320S. [PubMed: 12475808]

6. Rahman I, Biswas SK, Kode A. Oxidant and antioxidant balance in the airways and airway diseases. Eur J Pharmacol. 2006; 533:222-239. [PubMed: 16500642]

7. Kinnula VL, Crapo JD, Raivio KO. Generation and disposal of reactive oxygen metabolites in the lung. Lab Invest. 1995; 73:3-19. [PubMed: 7603038]

8. Church DF, Pryor WA. Free-radical chemistry of cigarette smoke and its toxicological implications. Environ Health Perspect. 1985; 64:111-126. [PubMed: 3007083]

9. Rahman I, MacNee W. Oxidative stress and regulation of glutathione in lung inflammation. Eur Respir J. 2000; 16:534-554. [PubMed: 11028671]

10. Wilce MC, Parker MW. Structure and function of glutathione S-transferases. Biochim Biophys Acta. 1994; 1205:1-18. [PubMed: 8142473]

11. Strange RC, Spiteri MA, Ramachandran S, Fryer AA. Glutathione-S-transferase family of enzymes. Mutat Res. 2001; 482:21-26. [PubMed: 11535245]

12. Nebert DW, Vasiliou V. Analysis of the glutathione S-transferase (GST) gene family. Hum Genomics. 2004; 1:460-464. [PubMed: 15607001]

13. Hayes JD, Flanagan JU, Jowsey IR. Glutathione transferases. Annu Rev Pharmacol Toxicol. 2005; 45:51-88. [PubMed: 15822171]

14. Ali-Osman F, Akande O, Antoun G, Mao JX, Buolamwini J. Molecular cloning, characterization, and expression in Escherichia coli of full-length cDNAs of three human glutathione S-transferase Pi gene variants. Evidence for differential catalytic activity of the encoded proteins. J Biol Chem. 1997; 272:10004-10012. [PubMed: 9092542]

15. Cotton SC, Sharp L, Little J, Brockton N. Glutathione S-transferase polymorphisms and colorectal cancer: a HuGE review. Am J Epidemiol. 2000; 151:7-32. [PubMed: 10625170]

16. Hou SM, Ryberg D, Falt S, Deverill A, Tefre T, Borresen AL, Haugen A, Lambert B. GSTM1 and NAT2 polymorphisms in operable and non-operable lung cancer patients. Carcinogenesis. 2000; 21:49-54. [PubMed: 10607733]

17. Hayes JD, McLellan LI. Glutathione and glutathione-dependent enzymes represent a co-ordinately regulated defence against oxidative stress. Free Radic Res. 1999; 31:273-300. [PubMed: 10517533]

18. Romieu I, Sienra-Monge JJ, Ramirez-Aguilar M, Moreno-Macias H, Reyes-Ruiz NI, Estela del Rio-Navarro B, Hernandez-Avila M, London SJ. Genetic polymorphism of GSTM1 and antioxidant supplementation influence lung function in relation to ozone exposure in asthmatic children in Mexico City. Thorax. 2004; 59:8-10. [PubMed: 14694237]

19. Tujague J, Bastaki M, Holland N, Balmes JR, Tager IB. Antioxidant intake, GSTM1 polymorphism and pulmonary function in healthy young adults. Eur Respir J. 2006; 27:282-288. [PubMed: 16452581]

20. Guo J, Zimniak L, Zimniak P, Orchard JL, Singh SV. Cloning and expression of a novel Mu class murine glutathione transferase isoenzyme. Biochem J. 2002; 366:817-824. [PubMed: 12069689]

21. Mitchell AE, Morin D, Lakritz J, Jones AD. Quantitative profiling of tissue- and gender-related expression of glutathione S-transferase isoenzymes in the mouse. Biochem J. 1997; 325(Pt 1):207216. [PubMed: 9224648]

22. Pearson WR, Vorachek WR, Xu SJ, Berger R, Hart I, Vannais D, Patterson D. Identification of class-mu glutathione transferase genes GSTM1-GSTM5 on human chromosome 1p13. Am J Hum Genet. 1993; 53:220-233. [PubMed: 8317488]

23. Xu S, Wang Y, Roe B, Pearson WR. Characterization of the human class Mu glutathione Stransferase gene cluster and the GSTM1 deletion. J Biol Chem. 1998; 273:3517-3527. [PubMed: 9452477] 
24. Takahashi Y, Campbell EA, Hirata Y, Takayama T, Listowsky I. A basis for differentiating among the multiple human Mu-glutathione S-transferases and molecular cloning of brain GSTM5. J Biol Chem. 1993; 268:8893-8898. [PubMed: 8473333]

25. Board PG. Biochemical genetics of glutathione-S-transferase in man. Am J Hum Genet. 1981; 33:36-43. [PubMed: 7468592]

26. Board PG. Gene deletion and partial deficiency of the glutathione S-transferase (ligandin) system in man. FEBS Lett. 1981; 135:12-14. [PubMed: 7319029]

27. Suzuki T, Coggan M, Shaw DC, Board PG. Electrophoretic and immunological analysis of human glutathione S-transferase isozymes. Ann Hum Genet. 1987; 51:95-106. [PubMed: 3118757]

28. Seidegard J, Vorachek WR, Pero RW, Pearson WR. Hereditary differences in the expression of the human glutathione transferase active on trans-stilbene oxide are due to a gene deletion. Proc Natl Acad Sci U S A. 1988; 85:7293-7297. [PubMed: 3174634]

29. Parl FF. Glutathione S-transferase genotypes and cancer risk. Cancer Lett. 2005; 221:123-129. [PubMed: 15808397]

30. Widersten M, Pearson WR, Engstrom A, Mannervik B. Heterologous expression of the allelic variant mu-class glutathione transferases mu and psi. Biochem J. 1991; 276(Pt 2):519-524. [PubMed: 2049077]

31. DeJong JL, Mohandas T, Tu CP. The human $\mathrm{Hb}(\mathrm{mu})$ class glutathione S-transferases are encoded by a dispersed gene family. Biochem Biophys Res Commun. 1991; 180:15-22. [PubMed: 1930212]

32. Evans DA, Seidegard J, Narayanan N. The GSTM1 genetic polymorphism in healthy Saudi Arabians and Filipinos, and Saudi Arabians with coronary atherosclerosis. Pharmacogenetics. 1996; 6:365-367. [PubMed: 8873224]

33. Sprenger R, Schlagenhaufer R, Kerb R, Bruhn C, Brockmoller J, Roots I, Brinkmann U. Characterization of the glutathione S-transferase GSTT1 deletion: discrimination of all genotypes by polymerase chain reaction indicates a trimodular genotype-phenotype correlation. Pharmacogenetics. 2000; 10:557-565. [PubMed: 10975610]

34. Carlsten C, Sagoo GS, Frodsham AJ, Burke W, Higgins JP. Glutathione S-transferase M1 (GSTM1) polymorphisms and lung cancer: a literature-based systematic HuGE review and metaanalysis. Am J Epidemiol. 2008; 167:759-774. [PubMed: 18270371]

35. Geisler SA, Olshan AF. GSTM1, GSTT1, and the risk of squamous cell carcinoma of the head and neck: a mini-HuGE review. Am J Epidemiol. 2001; 154:95-105. [PubMed: 11447041]

36. Vorachek WR, Pearson WR, Rule GS. Cloning, expression, and characterization of a class-mu glutathione transferase from human muscle, the product of the GST4 locus. Proc Natl Acad Sci U S A. 1991; 88:4443-4447. [PubMed: 2034681]

37. Hayes JD, Strange RC. Glutathione S-transferase polymorphisms and their biological consequences. Pharmacology. 2000; 61:154-166. [PubMed: 10971201]

38. Rowe JD, Nieves E, Listowsky I. Subunit diversity and tissue distribution of human glutathione Stransferases: interpretations based on electrospray ionization-MS and peptide sequence-specific antisera. Biochem J. 1997; 325(Pt 2):481-486. [PubMed: 9230131]

39. Hayes JD, Pulford DJ. The glutathione S-transferase supergene family: regulation of GST and the contribution of the isoenzymes to cancer chemoprotection and drug resistance. Crit Rev Biochem Mol Biol. 1995; 30:445-600. [PubMed: 8770536]

40. Laborde E. Glutathione transferases as mediators of signaling pathways involved in cell proliferation and cell death. Cell Death Differ. 2010; 17:1373-1380. [PubMed: 20596078]

41. Lo HW, Ali-Osman F. Genetic polymorphism and function of glutathione S-transferases in tumor drug resistance. Curr Opin Pharmacol. 2007; 7:367-374. [PubMed: 17681492]

42. Sau A, Pellizzari Tregno F, Valentino F, Federici G, Caccuri AM. Glutathione transferases and development of new principles to overcome drug resistance. Arch Biochem Biophys. 2010; 500:116-122. [PubMed: 20494652]

43. Cho SG, Lee YH, Park HS, Ryoo K, Kang KW, Park J, Eom SJ, Kim MJ, Chang TS, Choi SY, Shim J, Kim Y, Dong MS, Lee MJ, Kim SG, Ichijo H, Choi EJ. Glutathione S-transferase mu modulates the stress-activated signals by suppressing apoptosis signal-regulating kinase 1 . J Biol Chem. 2001; 276:12749-12755. [PubMed: 11278289] 
44. Gilot D, Loyer P, Corlu A, Glaise D, Lagadic-Gossmann D, Atfi A, Morel F, Ichijo H, GuguenGuillouzo C. Liver protection from apoptosis requires both blockage of initiator caspase activities and inhibition of ASK1/JNK pathway via glutathione S-transferase regulation. J Biol Chem. 2002; 277:49220-49229. [PubMed: 12370186]

45. Ekhart C, Rodenhuis S, Smits PH, Beijnen JH, Huitema AD. An overview of the relations between polymorphisms in drug metabolising enzymes and drug transporters and survival after cancer drug treatment. Cancer Treat Rev. 2009; 35:18-31. [PubMed: 18771857]

46. Guthenberg C, Warholm M, Rane A, Mannervik B. Two distinct forms of glutathione transferase from human foetal liver. Purification and comparison with isoenzymes isolated from adult liver and placenta. Biochem J. 1986; 235:741-745. [PubMed: 3092805]

47. Strange RC, Davis BA, Faulder CG, Cotton W, Bain AD, Hopkinson DA, Hume R. The human glutathione S-transferases: developmental aspects of the GST1, GST2, and GST3 loci. Biochem Genet. 1985; 23:1011-1028. [PubMed: 4084207]

48. Strange RC, Faulder CG, Davis BA, Hume R, Brown JA, Cotton W, Hopkinson DA. The human glutathione S-transferases: studies on the tissue distribution and genetic variation of the GST1, GST2 and GST3 isozymes. Ann Hum Genet. 1984; 48:11-20. [PubMed: 6712152]

49. Raijmakers MT, Steegers EA, Peters WH. Glutathione S-transferases and thiol concentrations in embryonic and early fetal tissues. Hum Reprod. 2001; 16:2445-2450. [PubMed: 11679536]

50. Anttila S, Hirvonen A, Vainio H, Husgafvel-Pursiainen K, Hayes JD, Ketterer B. Immunohistochemical localization of glutathione S-transferases in human lung. Cancer Res. 1993; 53:5643-5648. [PubMed: 8242618]

51. Mace K, Bowman ED, Vautravers P, Shields PG, Harris CC, Pfeifer AM. Characterisation of xenobiotic-metabolising enzyme expression in human bronchial mucosa and peripheral lung tissues. Eur J Cancer. 1998; 34:914-920. [PubMed: 9797707]

52. Cantlay AM, Smith CA, Wallace WA, Yap PL, Lamb D, Harrison DJ. Heterogeneous expression and polymorphic genotype of glutathione S-transferases in human lung. Thorax. 1994; 49:1010 1014. [PubMed: 7974294]

53. Pearson WR, Windle JJ, Morrow JF, Benson AM, Talalay P. Increased synthesis of glutathione Stransferases in response to anticarcinogenic antioxidants. Cloning and measurement of messenger RNA. J Biol Chem. 1983; 258:2052-2062. [PubMed: 6822548]

54. Kim SG, Lee SJ. PI3K, RSK, and mTOR signal networks for the GST gene regulation. Toxicol Sci. 2007; 96:206-213. [PubMed: 17122411]

55. Rushmore TH, Morton MR, Pickett CB. The antioxidant responsive element. Activation by oxidative stress and identification of the DNA consensus sequence required for functional activity. J Biol Chem. 1991; 266:11632-11639. [PubMed: 1646813]

56. Hayes JD, Chanas SA, Henderson CJ, McMahon M, Sun C, Moffat GJ, Wolf CR, Yamamoto M. The Nrf2 transcription factor contributes both to the basal expression of glutathione S-transferases in mouse liver and to their induction by the chemopreventive synthetic antioxidants, butylated hydroxyanisole and ethoxyquin. Biochem Soc Trans. 2000; 28:33-41. [PubMed: 10816095]

57. Enomoto A, Itoh K, Nagayoshi E, Haruta J, Kimura T, O'Connor T, Harada T, Yamamoto M. High sensitivity of Nrf2 knockout mice to acetaminophen hepatotoxicity associated with decreased expression of ARE-regulated drug metabolizing enzymes and antioxidant genes. Toxicol Sci. 2001; 59:169-177. [PubMed: 11134556]

58. Ishii T, Itoh K, Yamamoto M. Roles of Nrf2 in activation of antioxidant enzyme genes via antioxidant responsive elements. Methods Enzymol. 2002; 348:182-190. [PubMed: 11885271]

59. Kwak MK, Itoh K, Yamamoto M, Sutter TR, Kensler TW. Role of transcription factor Nrf2 in the induction of hepatic phase 2 and antioxidative enzymes in vivo by the cancer chemoprotective agent, 3H-1, 2-dimethiole-3-thione. Mol Med. 2001; 7:135-145. [PubMed: 11471548]

60. McMahon M, Itoh K, Yamamoto M, Chanas SA, Henderson CJ, McLellan LI, Wolf CR, Cavin C, Hayes JD. The Cap'n'Collar basic leucine zipper transcription factor Nrf2 (NF-E2 p45-related factor 2) controls both constitutive and inducible expression of intestinal detoxification and glutathione biosynthetic enzymes. Cancer Res. 2001; 61:3299-3307. [PubMed: 11309284] 
61. Giudice A, Arra C, Turco MC. Review of molecular mechanisms involved in the activation of the Nrf2-ARE signaling pathway by chemopreventive agents. Methods Mol Biol. 2010; 647:37-74. [PubMed: 20694660]

62. Rahman I. Regulation of glutathione in inflammation and chronic lung diseases. Mutat Res. 2005; 579:58-80. [PubMed: 16054171]

63. Kleeberger SR, Peden D. Gene-environment interactions in asthma and other respiratory diseases. Annu Rev Med. 2005; 56:383-400. [PubMed: 15660518]

64. Kleeberger SR. Genetic aspects of pulmonary responses to inhaled pollutants. Exp Toxicol Pathol. 2005; 57(Suppl 1):147-153. [PubMed: 16092722]

65. Romieu I, Moreno-Macias H, London SJ. Gene by environment interaction and ambient air pollution. Proc Am Thorac Soc. 2010; 7:116-122. [PubMed: 20427582]

66. Minelli C, Wei I, Sagoo G, Jarvis D, Shaheen S, Burney P. Interactive effects of antioxidant genes and air pollution on respiratory function and airway disease: a HuGE review. Am J Epidemiol. 2011; 173:603-620. [PubMed: 21343247]

67. Hirvonen A. Gene-environment interactions in chronic pulmonary diseases. Mutat Res. 2009; 667:132-141. [PubMed: 19563928]

68. Yang IA, Fong KM, Zimmerman PV, Holgate ST, Holloway JW. Genetic susceptibility to the respiratory effects of air pollution. Postgrad Med J. 2009; 85:428-436. [PubMed: 19633009]

69. Barnes PJ. Immunology of asthma and chronic obstructive pulmonary disease. Nat Rev Immunol. 2008; 8:183-192. [PubMed: 18274560]

70. McCunney RJ. Asthma, genes, and air pollution. J Occup Environ Med. 2005; 47:1285-1291. [PubMed: 16340710]

71. Ercan H, Birben E, Dizdar EA, Keskin O, Karaaslan C, Soyer OU, Dut R, Sackesen C, Besler T, Kalayci O. Oxidative stress and genetic and epidemiologic determinants of oxidant injury in childhood asthma. J Allergy Clin Immunol. 2006; 118:1097-1104. [PubMed: 17088135]

72. Ober C, Hoffjan S. Asthma genetics 2006: the long and winding road to gene discovery. Genes Immun. 2006; 7:95-100. [PubMed: 16395390]

73. Brasch-Andersen C, Christiansen L, Tan Q, Haagerup A, Vestbo J, Kruse TA. Possible gene dosage effect of glutathione-S-transferases on atopic asthma: using real-time PCR for quantification of GSTM1 and GSTT1 gene copy numbers. Hum Mutat. 2004; 24:208-214. [PubMed: 15300848]

74. Hanene C, Jihene L, Jamel A, Kamel H, Agnes H. Association of GST genes polymorphisms with asthma in Tunisian children. Mediators Inflamm. 2007; 2007:19564. [PubMed: 17497028]

75. Saadat M, Ansari-Lari M. Genetic polymorphism of glutathione S-transferase T1, M1 and asthma, a meta-analysis of the literature. Pak J Biol Sci. 2007; 10:4183-4189. [PubMed: 19086569]

76. Salam MT, Lin PC, Avol EL, Gauderman WJ, Gilliland FD. Microsomal epoxide hydrolase, glutathione S-transferase P1, traffic and childhood asthma. Thorax. 2007; 62:1050-1057. [PubMed: 17711870]

77. Joubert BR, Reif DM, Edwards SW, Leiner KA, Hudgens EE, Egeghy P, Gallagher JE, Hubal EC. Evaluation of genetic susceptibility to childhood allergy and asthma in an African American urban population. BMC Med Genet. 2011; 12:25. [PubMed: 21320344]

78. Holla LI, Stejskalova A, Vasku A. Polymorphisms of the GSTM1 and GSTT1 genes in patients with allergic diseases in the Czech population. Allergy. 2006; 61:265-267. [PubMed: 16409207]

79. Fryer AA, Bianco A, Hepple M, Jones PW, Strange RC, Spiteri MA. Polymorphism at the glutathione S-transferase GSTP1 locus. A new marker for bronchial hyperresponsiveness and asthma. Am J Respir Crit Care Med. 2000; 161:1437-1442. [PubMed: 10806136]

80. Gilliland FD, Rappaport EB, Berhane K, Islam T, Dubeau L, Gauderman WJ, McConnell R. Effects of glutathione S-transferase P1, M1, and T1 on acute respiratory illness in school children. Am J Respir Crit Care Med. 2002; 166:346-351. [PubMed: 12153968]

81. Piacentini S, Verrotti A, Polimanti R, Giannini C, Saccucci P, Manfellotto D, Fuciarelli M. Functional polymorphisms of GSTA1 and GSTO2 genes associated with asthma in Italian children. Clin Chem Lab Med. 2011 
82. Reddy P, Naidoo RN, Robins TG, Mentz G, London SJ, Li H, Naidoo R. GSTM1, GSTP1, and NQO1 polymorphisms and susceptibility to atopy and airway hyperresponsiveness among South African schoolchildren. Lung. 2010; 188:409-414. [PubMed: 20526719]

83. Minelli C, Granell R, Newson R, Rose-Zerilli MJ, Torrent M, Ring SM, Holloway JW, Shaheen SO, Henderson JA. Glutathione-S-transferase genes and asthma phenotypes: a Human Genome Epidemiology (HuGE) systematic review and meta-analysis including unpublished data. Int $\mathbf{J}$ Epidemiol. 2010; 39:539-562. [PubMed: 20032267]

84. Eaton DL, Bammler TK. Concise review of the glutathione S-transferases and their significance to toxicology. Toxicol Sci. 1999; 49:156-164. [PubMed: 10416260]

85. Tamer L, Calikoglu M, Ates NA, Yildirim H, Ercan B, Saritas E, Unlu A, Atik U. Glutathione-Stransferase gene polymorphisms (GSTT1, GSTM1, GSTP1) as increased risk factors for asthma. Respirology. 2004; 9:493-498. [PubMed: 15612961]

86. Islam T, Berhane K, McConnell R, Gauderman WJ, Avol E, Peters JM, Gilliland FD. GlutathioneS-transferase (GST) P1, GSTM1, exercise, ozone and asthma incidence in school children. Thorax. 2009; 64:197-202. [PubMed: 18988661]

87. David GL, Romieu I, Sienra-Monge JJ, Collins WJ, Ramirez-Aguilar M, del Rio-Navarro BE, Reyes-Ruiz NI, Morris RW, Marzec JM, London SJ. Nicotinamide adenine dinucleotide (phosphate) reduced:quinone oxidoreductase and glutathione S-transferase M1 polymorphisms and childhood asthma. Am J Respir Crit Care Med. 2003; 168:1199-1204. [PubMed: 12969868]

88. Carroll WD, Lenney W, Jones PW, Strange RC, Child F, Whyte MK, Primhak RA, Fryer AA. Effects of glutathione S-transferase M1, T1 and P1 on lung function in asthmatic families. Clin Exp Allergy. 2005; 35:1155-1161. [PubMed: 16164441]

89. Lee YL, Hsiue TR, Lee YC, Lin YC, Guo YL. The association between glutathione S-transferase P1, M1 polymorphisms and asthma in Taiwanese schoolchildren. Chest. 2005; 128:1156-1162. [PubMed: 16162701]

90. Kamada F, Mashimo Y, Inoue H, Shao C, Hirota T, Doi S, Kameda M, Fujiwara H, Fujita K, Enomoto T, Sasaki S, Endo H, Takayanagi R, Nakazawa C, Morikawa T, Morikawa M, Miyabayashi S, Chiba Y, Tamura G, Shirakawa T, Matsubara Y, Hata A, Tamari M, Suzuki Y. The GSTP1 gene is a susceptibility gene for childhood asthma and the GSTM1 gene is a modifier of the GSTP1 gene. Int Arch Allergy Immunol. 2007; 144:275-286. [PubMed: 17643058]

91. Li YF, Tseng PJ, Lin CC, Hung CL, Lin SC, Su WC, Huang YL, Sung FC, Tai CK. NAD(P)H: Quinone oxidoreductase 1, glutathione S-transferase M1, environmental tobacco smoke exposure, and childhood asthma. Mutat Res. 2009; 678:53-58. [PubMed: 19591959]

92. Islam T, Breton C, Salam MT, McConnell R, Wenten M, Gauderman WJ, Conti D, Van Den Berg D, Peters JM, Gilliland FD. Role of inducible nitric oxide synthase in asthma risk and lung function growth during adolescence. Thorax. 2010; 65:139-145. [PubMed: 19996333]

93. Piirila P, Wikman H, Luukkonen R, Kaaria K, Rosenberg C, Nordman H, Norppa H, Vainio H, Hirvonen A. Glutathione S-transferase genotypes and allergic responses to diisocyanate exposure. Pharmacogenetics. 2001; 11:437-445. [PubMed: 11470996]

94. Wikman H, Piirila P, Rosenberg C, Luukkonen R, Kaaria K, Nordman H, Norppa H, Vainio H, Hirvonen A. N-Acetyltransferase genotypes as modifiers of diisocyanate exposure-associated asthma risk. Pharmacogenetics. 2002; 12:227-233. [PubMed: 11927838]

95. Littorin M, Hou S, Broberg K, Bjork J, Falt S, Abdoulaye G, Kalemba M, Ryk C, Skerfving S. Influence of polymorphic metabolic enzymes on biotransformation and effects of diphenylmethane diisocyanate. Int Arch Occup Environ Health. 2008; 81:429-441. [PubMed: 17676332]

96. Peden DB. Air pollution in asthma: effect of pollutants on airway inflammation. Ann Allergy Asthma Immunol. 2001; 87:12-17. [PubMed: 11770676]

97. Peden DB. Effect of air pollution in asthma and respiratory allergy. Otolaryngol Head Neck Surg. 1996; 114:242-247. [PubMed: 8637742]

98. London SJ. Gene-air pollution interactions in asthma. Proc Am Thorac Soc. 2007; 4:217-220. [PubMed: 17607002]

99. Diaz-Sanchez D, Tsien A, Fleming J, Saxon A. Combined diesel exhaust particulate and ragweed allergen challenge markedly enhances human in vivo nasal ragweed-specific IgE and skews 
cytokine production to a T helper cell 2-type pattern. J Immunol. 1997; 158:2406-2413. [PubMed: 9036991]

100. Gilliland FD, Li YF, Saxon A, Diaz-Sanchez D. Effect of glutathione-S-transferase M1 and P1 genotypes on xenobiotic enhancement of allergic responses: randomised, placebo-controlled crossover study. Lancet. 2004; 363:119-125. [PubMed: 14726165]

101. Peden DB, Setzer RW Jr, Devlin RB. Ozone exposure has both a priming effect on allergeninduced responses and an intrinsic inflammatory action in the nasal airways of perennially allergic asthmatics. Am J Respir Crit Care Med. 1995; 151:1336-1345. [PubMed: 7735583]

102. Peden DB. The role of oxidative stress and innate immunity in $\mathrm{O}(3)$ and endotoxin-induced human allergic airway disease. Immunol Rev. 2011; 242:91-105. [PubMed: 21682740]

103. Romieu I, Ramirez-Aguilar M, Sienra-Monge JJ, Moreno-Macias H, del Rio-Navarro BE, David G, Marzec J, Hernandez-Avila M, London S. GSTM1 and GSTP1 and respiratory health in asthmatic children exposed to ozone. Eur Respir J. 2006; 28:953-959. [PubMed: 16870661]

104. Gilliland FD, Li YF, Dubeau L, Berhane K, Avol E, McConnell R, Gauderman WJ, Peters JM. Effects of glutathione S-transferase M1, maternal smoking during pregnancy, and environmental tobacco smoke on asthma and wheezing in children. Am J Respir Crit Care Med. 2002; 166:457463. [PubMed: 12186820]

105. Palmer CN, Doney AS, Lee SP, Murrie I, Ismail T, Macgregor DF, Mukhopadhyay S. Glutathione S-transferase M1 and P1 genotype, passive smoking, and peak expiratory flow in asthma. Pediatrics. 2006; 118:710-716. [PubMed: 16882827]

106. Kabesch M, Hoefler C, Carr D, Leupold W, Weiland SK, von Mutius E. Glutathione S transferase deficiency and passive smoking increase childhood asthma. Thorax. 2004; 59:569-573. [PubMed: 15223862]

107. Melen E, Nyberg F, Lindgren CM, Berglind N, Zucchelli M, Nordling E, Hallberg J, Svartengren M, Morgenstern R, Kere J, Bellander T, Wickman M, Pershagen G. Interactions between glutathione S-transferase P1, tumor necrosis factor, and traffic-related air pollution for development of childhood allergic disease. Environ Health Perspect. 2008; 116:1077-1084. [PubMed: 18709160]

108. Yang IA, Fong KM, Zimmerman PV, Holgate ST, Holloway JW. Genetic susceptibility to the respiratory effects of air pollution. Thorax. 2008; 63:555-563. [PubMed: 18511640]

109. Salam MT, Islam T, Gilliland FD. Recent evidence for adverse effects of residential proximity to traffic sources on asthma. Curr Opin Pulm Med. 2008; 14:3-8. [PubMed: 18043269]

110. Breton CV, Byun HM, Wenten M, Pan F, Yang A, Gilliland FD. Prenatal tobacco smoke exposure affects global and gene-specific DNA methylation. Am J Respir Crit Care Med. 2009; 180:462-467. [PubMed: 19498054]

111. Silverman EK. Progress in chronic obstructive pulmonary disease genetics. Proc Am Thorac Soc. 2006; 3:405-408. [PubMed: 16799082]

112. Mannino DM. COPD: epidemiology, prevalence, morbidity and mortality, and disease heterogeneity. Chest. 2002; 121:121S-126S. [PubMed: 12010839]

113. Barnes PJ, Shapiro SD, Pauwels RA. Chronic obstructive pulmonary disease: molecular and cellular mechanisms. Eur Respir J. 2003; 22:672-688. [PubMed: 14582923]

114. Nakamura H. Genetics of COPD. Allergol Int. 2011; 60:253-258. [PubMed: 21778810]

115. Silverman EK, Palmer LJ. Case-control association studies for the genetics of complex respiratory diseases. Am J Respir Cell Mol Biol. 2000; 22:645-648. [PubMed: 10837359]

116. Sandford AJ, Pare PD. Genetic risk factors for chronic obstructive pulmonary disease. Clin Chest Med. 2000; 21:633-643. [PubMed: 11194775]

117. Castaldi PJ, Cho MH, Cohn M, Langerman F, Moran S, Tarragona N, Moukhachen H, Venugopal R, Hasimja D, Kao E, Wallace B, Hersh CP, Bagade S, Bertram L, Silverman EK, Trikalinos TA. The COPD genetic association compendium: a comprehensive online database of COPD genetic associations. Hum Mol Genet. 2010; 19:526-534. [PubMed: 19933216]

118. Lakhdar R, Denden S, Knani J, Leban N, Daimi H, Hassine M, Lefranc G, Chibani JB, Khelil AH. Combined analysis of EPHX1, GSTP1, GSTM1 and GSTT1 gene polymorphisms in relation to chronic obstructive pulmonary disease risk and lung function impairment. Dis Markers. 2011; 30:253-263. [PubMed: 21734345] 
119. Lakhdar R, Denden S, Mouhamed MH, Chalgoum A, Leban N, Knani J, Lefranc G, Miled A, Ben Chibani J, Khelil AH. Correlation of EPHX1, GSTP1, GSTM1, and GSTT1 genetic polymorphisms with antioxidative stress markers in chronic obstructive pulmonary disease. Exp Lung Res. 2011; 37:195-204. [PubMed: 21309732]

120. Shukla RK, Kant S, Bhattacharya S, Mittal B. Association of genetic polymorphism of GSTT1, GSTM1 and GSTM3 in COPD patients in a north Indian population. Copd. 2011; 8:167-172. [PubMed: 21513434]

121. Chan-Yeung M, Ho SP, Cheung AH, So LK, Wong PC, Chan KK, Chan JW, Ip MS, Mak JC. Polymorphisms of glutathione S-transferase genes and functional activity in smokers with or without COPD. Int J Tuberc Lung Dis. 2007; 11:508-514. [PubMed: 17439673]

122. Xue H, Su J, Sun K, Xie W, Wang H. Glutathione S-transferase M1 and T1 gene polymorphism and COPD risk in smokers: an updated analysis. Mol Biol Rep. 2011

123. Cheng SL, Yu CJ, Chen CJ, Yang PC. Genetic polymorphism of epoxide hydrolase and glutathione S-transferase in COPD. Eur Respir J. 2004; 23:818-824. [PubMed: 15218992]

124. Calikoglu M, Tamer L, Ates Aras N, Karakas S, Ercan B. The association between polymorphic genotypes of glutathione S-transferases and COPD in the Turkish population. Biochem Genet. 2006; 44:307-319. [PubMed: 16977512]

125. Zidzik J, Slaba E, Joppa P, Kluchova Z, Dorkova Z, Skyba P, Habalova V, Salagovic J, Tkacova R. Glutathione S-transferase and microsomal epoxide hydrolase gene polymorphisms and risk of chronic obstructive pulmonary disease in Slovak population. Croat Med J. 2008; 49:182-191. [PubMed: 18461673]

126. Tomaki M, Sugiura H, Koarai A, Komaki Y, Akita T, Matsumoto T, Nakanishi A, Ogawa H, Hattori T, Ichinose M. Decreased expression of antioxidant enzymes and increased expression of chemokines in COPD lung. Pulm Pharmacol Ther. 2007; 20:596-605. [PubMed: 16919984]

127. Tkacova R, Salagovic J, Ceripkova M, Tkac I, Stubna J, Kalina I. Glutathione S-transferase M1 gene polymorphism is related to COPD in patients with non-small-cell lung cancer. Wien Klin Wochenschr. 2004; 116:131-134. [PubMed: 15038404]

128. Bergamaschi E, De Palma G, Mozzoni P, Vanni S, Vettori MV, Broeckaert F, Bernard A, Mutti A. Polymorphism of quinone-metabolizing enzymes and susceptibility to ozone-induced acute effects. Am J Respir Crit Care Med. 2001; 163:1426-1431. [PubMed: 11371413]

129. Corradi M, Alinovi R, Goldoni M, Vettori M, Folesani G, Mozzoni P, Cavazzini S, Bergamaschi E, Rossi L, Mutti A. Biomarkers of oxidative stress after controlled human exposure to ozone. Toxicol Lett. 2002; 134:219-225. [PubMed: 12191881]

130. Alexis NE, Zhou H, Lay JC, Harris B, Hernandez ML, Lu TS, Bromberg PA, Diaz-Sanchez D, Devlin RB, Kleeberger SR, Peden DB. The glutathione-S-transferase Mu 1 null genotype modulates ozone-induced airway inflammation in human subjects. J Allergy Clin Immunol. 2009; 124:1222-1228. e1225. [PubMed: 19796798]

131. Kim CS, Alexis NE, Rappold AG, Kehrl H, Hazucha MJ, Lay JC, Schmitt MT, Case M, Devlin RB, Peden DB, Diaz-Sanchez D. Lung function and inflammatory responses in healthy young adults exposed to 0.06 ppm ozone for 6.6 hours. Am J Respir Crit Care Med. 2011; 183:12151221. [PubMed: 21216881]

132. Vagaggini B, Bartoli ML, Cianchetti S, Costa F, Bacci E, Dente FL, Di Franco A, Malagrino L, Paggiaro P. Increase in markers of airway inflammation after ozone exposure can be observed also in stable treated asthmatics with minimal functional response to ozone. Respir Res. 2010; 11:5. [PubMed: 20085630]

133. Dillon MA, Harris B, Hernandez ML, Zou B, Reed W, Bromberg PA, Devlin RB, Diaz-Sanchez D, Kleeberger S, Zhou H, Lay JC, Alexis NE, Peden DB. Enhancement of systemic and sputum granulocyte response to inhaled endotoxin in people with the GSTM1 null genotype. Occup Environ Med. 2011

134. Saxon A, Diaz-Sanchez D. Air pollution and allergy: you are what you breathe. Nat Immunol. 2005; 6:223-226. [PubMed: 15716966]

135. Gilliland FD, Li YF, Gong H Jr, Diaz-Sanchez D. Glutathione s-transferases M1 and P1 prevent aggravation of allergic responses by secondhand smoke. Am J Respir Crit Care Med. 2006; 174:1335-1341. [PubMed: 17023730] 
136. Fujimoto K, Arakawa S, Shibaya Y, Miida H, Ando Y, Yasumo H, Hara A, Uchiyama M, Iwabuchi H, Takasaki W, Manabe S, Yamoto T. Characterization of phenotypes in Gstm1-null mice by cytosolic and in vivo metabolic studies using 1,2-dichloro-4-nitrobenzene. Drug Metab Dispos. 2006; 34:1495-1501. [PubMed: 16760226]

137. Yochum CL, Bhattacharya P, Patti L, Mirochnitchenko O, Wagner GC. Animal model of autism using GSTM1 knockout mice and early post-natal sodium valproate treatment. Behav Brain Res. 2010; 210:202-210. [PubMed: 20178820]

138. Cho HY, Jedlicka AE, Reddy SP, Kensler TW, Yamamoto M, Zhang LY, Kleeberger SR. Role of NRF2 in protection against hyperoxic lung injury in mice. Am J Respir Cell Mol Biol. 2002; 26:175-182. [PubMed: 11804867]

139. Aoki Y, Sato H, Nishimura N, Takahashi S, Itoh K, Yamamoto M. Accelerated DNA adduct formation in the lung of the Nrf2 knockout mouse exposed to diesel exhaust. Toxicol Appl Pharmacol. 2001; 173:154-160. [PubMed: 11437637]

140. Wu W, Doreswamy V, Diaz-Sanchez D, Samet JM, Kesic M, Dailey L, Zhang W, Jaspers I, Peden DB. GSTM1 modulation of IL-8 expression in human bronchial epithelial cells exposed to ozone. Free Radic Biol Med. 2011; 51:522-529. [PubMed: 21621609]

141. Kesic MJ, Simmons SO, Bauer R, Jaspers I. Nrf2 expression modifies influenza A entry and replication in nasal epithelial cells. Free Radic Biol Med. 2011; 51:444-453. [PubMed: 21549835]

142. Rahman I, Adcock IM. Oxidative stress and redox regulation of lung inflammation in COPD. Eur Respir J. 2006; 28:219-242. [PubMed: 16816350]

143. Awasthi, YC. Toxicology of glutathione transferases. CRC Press Taylor \& Francis Group; 2007.

144. McIlwain CC, Townsend DM, Tew KD. Glutathione S-transferase polymorphisms: cancer incidence and therapy. Oncogene. 2006; 25:1639-1648. [PubMed: 16550164]

145. Ichijo H, Nishida E, Irie K, ten Dijke P, Saitoh M, Moriguchi T, Takagi M, Matsumoto K, Miyazono K, Gotoh Y. Induction of apoptosis by ASK1, a mammalian MAPKKK that activates SAPK/JNK and p38 signaling pathways. Science. 1997; 275:90-94. [PubMed: 8974401]

146. Saitoh M, Nishitoh H, Fujii M, Takeda K, Tobiume K, Sawada Y, Kawabata M, Miyazono K, Ichijo H. Mammalian thioredoxin is a direct inhibitor of apoptosis signal-regulating kinase (ASK) 1. Embo J. 1998; 17:2596-2606. [PubMed: 9564042]

147. Dorion S, Lambert H, Landry J. Activation of the p38 signaling pathway by heat shock involves the dissociation of glutathione S-transferase Mu from Ask1. J Biol Chem. 2002; 277:3079230797. [PubMed: 12077134]

148. Ryoo K, Huh SH, Lee YH, Yoon KW, Cho SG, Choi EJ. Negative regulation of MEKK1-induced signaling by glutathione S-transferase Mu. J Biol Chem. 2004; 279:43589-43594. [PubMed: 15299005]

149. Sundberg K, Widersten M, Seidel A, Mannervik B, Jernstrom B. Glutathione conjugation of bayand fjord-region diol epoxides of polycyclic aromatic hydrocarbons by glutathione transferases M1-1 and P1-1. Chem Res Toxicol. 1997; 10:1221-1227. [PubMed: 9403173]

150. Chung S, Sundar IK, Yao H, Ho YS, Rahman I. Glutaredoxin 1 regulates cigarette smokemediated lung inflammation through differential modulation of I $\{$ kappa $\}$ B kinases in mice: impact on histone acetylation. Am J Physiol Lung Cell Mol Physiol. 2010; 299:L192-L203. [PubMed: 20472709]

151. Yang Y, Parsons KK, Chi L, Malakauskas SM, Le TH. Glutathione S-transferase-micro1 regulates vascular smooth muscle cell proliferation, migration, and oxidative stress. Hypertension. 2009; 54:1360-1368. [PubMed: 19822795]

152. Traka M, Gasper AV, Melchini A, Bacon JR, Needs PW, Frost V, Chantry A, Jones AM, Ortori CA, Barrett DA, Ball RY, Mills RD, Mithen RF. Broccoli consumption interacts with GSTM1 to perturb oncogenic signalling pathways in the prostate. PLoS One. 2008; 3:e2568. [PubMed: 18596959]

153. Fahey JW, Zhang Y, Talalay P. Broccoli sprouts: an exceptionally rich source of inducers of enzymes that protect against chemical carcinogens. Proc Natl Acad Sci U S A. 1997; 94:1036710372. [PubMed: 9294217] 
154. Ritz SA, Wan J, Diaz-Sanchez D. Sulforaphane-stimulated phase II enzyme induction inhibits cytokine production by airway epithelial cells stimulated with diesel extract. Am J Physiol Lung Cell Mol Physiol. 2007; 292:L33-L39. [PubMed: 16905640]

155. Harvey CJ, Thimmulappa RK, Sethi S, Kong X, Yarmus L, Brown RH, Feller-Kopman D, Wise $\mathrm{R}$, Biswal S. Targeting Nrf2 signaling improves bacterial clearance by alveolar macrophages in patients with COPD and in a mouse model. Sci Transl Med. 2011; 3:78ra32.

156. Wan J, Diaz-Sanchez D. Antioxidant enzyme induction: a new protective approach against the adverse effects of diesel exhaust particles. Inhal Toxicol. 2007; 19(Suppl 1):177-182. [PubMed: 17886065]

157. Riedl MA, Saxon A, Diaz-Sanchez D. Oral sulforaphane increases Phase II antioxidant enzymes in the human upper airway. Clin Immunol. 2009; 130:244-251. [PubMed: 19028145]

158. Forman HJ, Dickinson DA. Oxidative signaling and glutathione synthesis. Biofactors. 2003; 17:1-12. [PubMed: 12897423]

159. Witschi A, Reddy S, Stofer B, Lauterburg BH. The systemic availability of oral glutathione. Eur J Clin Pharmacol. 1992; 43:667-669. [PubMed: 1362956]

160. Allen J, Bradley RD. Effects of oral glutathione supplementation on systemic oxidative stress biomarkers in human volunteers. J Altern Complement Med. 2011; 17:827-833. [PubMed: 21875351]

161. Cardon LR, Bell JI. Association study designs for complex diseases. Nat Rev Genet. 2001; 2:9199. [PubMed: 11253062]

162. London SJ, Romieu I. Gene by environment interaction in asthma. Annu Rev Public Health. 2009; 30:55-80. [PubMed: 18980546]

163. Bentley AR, Emrani P, Cassano PA. Genetic variation and gene expression in antioxidant related enzymes and risk of COPD: a systematic review. Thorax. 2008; 63:956-961. [PubMed: 18566111] 


\section{Highlights}

- GSTM1 gene expression, function, and regulation are reviewed.

- GSTM1 acts through interactions with other genes and environmental factors.

- Pharmacologic and genetic manipulation of the GSTM1 gene was discussed. 